\title{
WPŁYW WIEDZY NA KONKURENCYJNOŚĆ PRZEDSIĘBIORSTW Z SEKTORA MŚP
}

\author{
Izabela Bagińska \\ Politechnika Częstochowska \\ Wydział Zarządzania
}

\begin{abstract}
Streszczenie: Przedsiębiorstwa nieustannie poszukują sposobów na wzmocnienie swej przewagi konkurencyjnej. Osiągnięcie tego celu w dużej mierze zależy od właściwego zarządzania wiedzą. Wiedza stanowi obecnie jeden $\mathrm{z}$ ważniejszych zasobów każdego przedsiębiorstwa. Na szczególną zaś uwagę zasługuje wiedza pracowników, która w większości znajduje się w ich umysłach. Zatem o konkurencyjności przedsiębiorstwa w znacznej mierze decydują wybitne jednostki i zespoły pracownicze oraz posiadana przez nie wiedza. Celem badawczym publikacji jest przedstawienie wpływu wiedzy na budowanie przewagi konkurencyjnej małych i średnich przedsiębiorstw. Badanie zostało przeprowadzone na grupie losowo wybranych przedsiębiorstw funkcjonujących w Polsce, w województwie śląskim, przy wykorzystaniu metody ankietowej. Rezultaty badań pozwalają stwierdzić, że przedsiębiorstwa oparte na wiedzy to najbardziej konkurencyjne przedsiębiorstwa.
\end{abstract}

Słowa kluczowe: konkurencyjność, wiedza, zarządzanie wiedzą

DOI: $10.17512 /$ znpcz.2017.4.1.13

\section{Wprowadzenie}

W wyniku przemian społeczno-gospodarczych nastąpił rozwój gospodarki opartej na wiedzy. Obecnie najważniejszym potencjałem przedsiębiorstwa stał się kapitał intelektualny. Szacuje się, że około $42 \%$ wiedzy znajduje się w umysłach pracowników (Malhotra 2001). Rolą przedsiębiorstwa jest wspierać wybitne jednostki w rozwoju wiedzy.

Uzyskanie przewagi konkurencyjnej w dużej mierze zależy od stanu wiedzy, umiejętności ciągłego doskonalenia i kapitału intelektualnego w przedsiębiorstwie. To od ludzi kreatywnych, dysponujących wiadomościami specjalnymi zależy sukces firmy. Jest on osiągany dzięki odpowiedniej strategii oraz posiadanym zasobom. Wśród tych zasobów zaś szczególne miejsce zajmują pracownicy oraz wiedza, jaką dysponują.

\section{Zasoby ludzkie jako czynnik wpływający na konkurencyjność przedsiębiorstw z sektora MŚP}

Ustawa o swobodzie działalności gospodarczej dzieli przedsiębiorstwa na mikro, małe i średnie (MŚP - sektor publiczny i prywatny, grupujący średnie, małe przedsiębiorstwa oraz mikroprzedsiębiorstwa, termin międzynarodowy stosowany w krajach Unii Europejskiej oraz między innymi przez Organizację Narodów 
Zjednoczonych, Światową Organizację Handlu, Bank Światowy). W Tabeli 1 przedstawiono kryteria podziału przedsiębiorstw zgodnie z powołaną ustawą.

Tabela 1. Kryteria podziału przedsiębiorstw według wielkości

\begin{tabular}{|l|l|l|l|}
\cline { 2 - 4 } \multicolumn{1}{c|}{} & \multicolumn{1}{c|}{$\begin{array}{c}\text { Mikroprzedsiębiorstw } \\
\text { a }\end{array}$} & $\begin{array}{c}\text { Małe } \\
\text { przedsiębiorstwa }\end{array}$ & $\begin{array}{c}\text { Średnie } \\
\text { przedsiębiorstwa }\end{array}$ \\
\hline Zatrudnienie & $<10$ osób & $<50$ osób & $<250$ osób \\
\hline $\begin{array}{l}\text { Przychód } \\
\text { ze sprzedaży }\end{array}$ & $<2 \mathrm{mln}$ euro & $<10 \mathrm{mln}$ euro & $<50 \mathrm{mln}$ euro \\
\hline $\begin{array}{l}\text { Suma } \\
\text { aktywów } \\
\text { bilansu }\end{array}$ & $<2 \mathrm{mln}$ euro & $<10 \mathrm{mln}$ euro & $<43 \mathrm{mln}$ euro \\
\hline
\end{tabular}

Źródło: Opracowanie własne na podstawie ustawy o swobodzie działalności gospodarczej

(Ustawa z dnia 2 lipca 2004 r. ...)

Małe i średnie przedsiębiorstwa w istotny sposób wpływają na rozwój gospodarki. Według danych GUS przedsiębiorstwa w Polsce generują blisko trzy czwarte polskiego PKB (PARP 2017, s. 5). Na kondycję MŚP oraz ich konkurencyjność wpływ ma wiele czynników, jednak posiadane zasoby wiedzy w istotny sposób przyczyniają się do uzyskania przewagi konkurencyjnej. Tak jak inne zasoby, również wiedza wymaga sprawnego zarządzania. Aby przedsiębiorstwo było bardziej konkurencyjne, musi w umiejętny sposób pozyskiwać, przetwarzać i zarządzać wiedzą.

Konkurencyjność to zdolność do konkurowania. Konkurencyjność jest nie tylko wartością społecznie użyteczną. Ma również wpływ na politykę firmy i podejmowane decyzje. Każde przedsiębiorstwo dąży do uzyskania przewagi konkurencyjnej, rozumianej jako bycie bardziej atrakcyjnym partnerem, w rezultacie czego odnosi sukces.

Według M.J. Stankiewicza konkurencyjność jest determinowana przez cztery czynniki (Stankiewicz 2002):

- potencjał konkurencyjności, czyli zasoby materialne i niematerialne, kluczowe kompetencje i zdolności, dzięki którym przedsiębiorstwo zdobywa przewagę konkurencyjną;

- przewagę konkurencyjną, czyli efekt skutecznego wykorzystywania składników potencjału konkurencyjności, dzięki któremu przedsiębiorstwo może generować atrakcyjną ofertę rynkową;

- instrumenty konkurowania, czyli narzędzia i metody budowania kapitału klientów oraz kreowania wartości firmy;

- pozycję konkurencyjną, czyli wynik konkurowania w danym sektorze.

Swoista definicję konkurencyjności podaje J. Owen. Według niego konkurencyjność to bycie mniej niekompetentnym niż inni (Owen 2003, s. 71). W praktyce jednak nie zawsze zdobywa się przewagę konkurencyjną tylko dlatego, że jest się bardziej kompetentnym niż rywale. 
Literatura przedmiotu wskazuje na wiele czynników, które wpływają na konkurencyjność przedsiębiorstw. Adamkiewicz dokonuje podziału tych czynników według dwóch kryteriów, co zobrazowano na Rysunku 1:

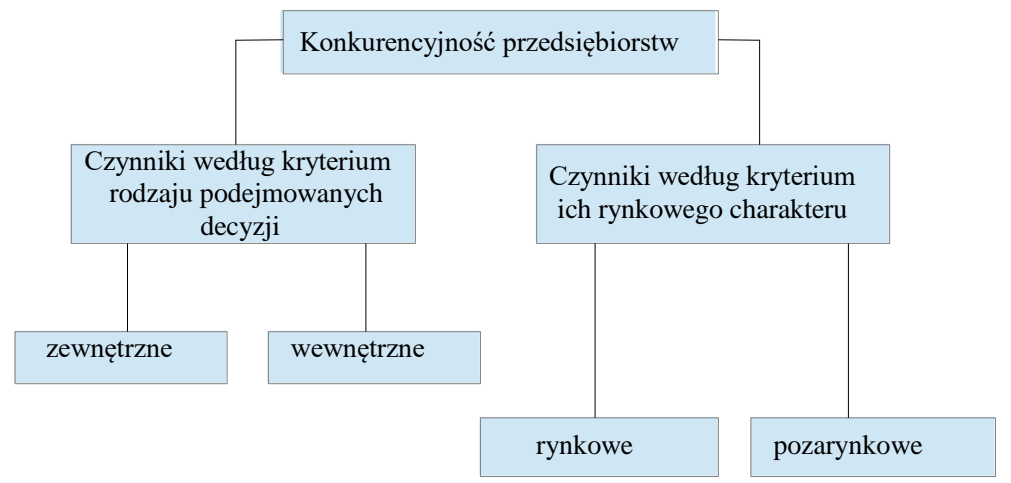

Rysunek 1. Czynniki wpływające na konkurencyjność przedsiębiorstw

Źródło: (Adamkiewicz-Drwiłło 2002, s. 129-131)

W modelu tym konkurencyjność traktowana jest jako system złożony z czterech powiązanych ze sobą elementów, podlegających oddziaływaniu otoczenia ogólnego i wchodzących w interaktywne relacje $\mathrm{z}$ bezpośrednim otoczeniem konkurencyjnym.

Rozwój przedsiębiorstwa zależy zarówno od zewnętrznych, jak i wewnętrznych czynników. Uwarunkowania zewnętrzne to takie, na które firma ma ograniczone możliwości oddziaływania. Jest to szeroko rozumiane otoczenie, z którego zasobów przedsiębiorstwo korzysta. Czynniki wewnętrzne z kolei to takie, na które firma ma możliwość bezpośredniego wpływu. Wśród nich najczęściej wymieniane są czynniki o charakterze kapitałowym i intelektualnym.

Wśród czynników wewnętrznych zasoby ludzkie zasługują na szczególną uwagę. Zarządzanie kapitałem ludzkim powinno zajmować znaczące miejsce w strategii rozwoju firmy. Patrząc z perspektywy czasu, można zauważyć, że zagadnienia dotyczące roli zasobów ludzkich w przedsiębiorstwie uległy istotnym przemianom. Jeszcze 20 lat temu nikt nie przypuszczał, że ekonomia i kultura korporacyjna tak wiele uwagi będą poświęcać metodom zarządzania kapitałem ludzkim.

Współczesnym przedsiębiorstwom do utrzymania przewagi konkurencyjnej nie wystarczają już same surowce, maszyny czy zaplecze finansowe. Dostrzeżono, że o sukcesie firmy w dużym stopniu decyduje poziom wiedzy, jaką ona dysponuje. $\mathrm{Na}$ szczególną zaś uwagę zasługuje wiedza pracowników, która w większości znajduje się w ich umyśle.

W wyniku przemyślanego zarządzania zasobami ludzkimi dochodzi do ich przekształcenia w kapitał firmy. Szczególnego znaczenia nabiera kultura organizacyjna oraz kompetencje menedżerów. Strategia przekształcania zasobów ludzkich w cenny dla firmy kapitał zachodzi poprzez (Król, Ludwiczyński 2006, s. 118-119):

- dostosowanie zatrudnienia do zmiennych warunków otoczenia, 
- oddziaływanie na otoczenie,

- organizowanie grup eksperckich wokół komórek kadrowych,

- nagradzanie za efektywną pracę,

- kształtowanie wewnętrznego rynku pracy firm.

Przedsiębiorstwa budują swą przewagę konkurencyjną przede wszystkim poprzez pozyskiwanie rynków, zdobywanie nowych źródeł zaopatrzenia, zwiększenie potencjału kapitału pracowniczego i zdobywanie nowych rynków zbytu. Style zarządzania, budowanie strategii, umiejętności i kompetencje są wynikiem twórczego myślenia i postaw ludzi zatrudnionych w przedsiębiorstwie. Zatem o konkurencyjności przedsiębiorstwa $\mathrm{w}$ znacznej mierze decydują wybitne jednostki i zespoły pracownicze funkcjonujące $\mathrm{w}$ przedsiębiorstwie oraz posiadana przez nie wiedza. $\mathrm{Z}$ tego względu ważne jest nie tylko tworzenie nowej wiedzy, którą mogliby przyswoić sobie pracownicy, ale również wykorzystywanie dotychczasowej.

\section{Rola i charakterystyka wiedzy w przedsiębiorstwach z sektora MŚP}

Zmiany zachodzące na świecie, w tym rozwój nauki, techniki, technologii, informatyki, w istotny sposób wpływają na rozwój przedsiębiorstw. Po przemianach społeczno-gospodarczych nastąpiło przejście z gospodarki industrialnej (przemysłowej) do postindustrialnej, która zgodnie z $\mathrm{OECD}^{1}$ zwana jest gospodarką opartą na wiedzy ${ }^{2}$.

Wiedza często utożsamiana jest $\mathrm{z}$ informacją, choć pojęcia te nie są identyczne. Niektóre przedsiębiorstwa mylą je, utożsamiając wprowadzane nowości technologiczne i nowe systemy informatyczne $\mathrm{z}$ nową wiedzą. Tymczasem jest to wyłącznie zarządzanie danymi lub informacjami. W literaturze istnieją poziomy zasobów wiedzy niematerialnej (Kisielnicki 2008, s. 255). Wiedza zajmuje miejsce pośrednie między informacją a mądrością. Najniższy poziom to dane, czyli poszczególne znaki, fakty, liczby, pewne szczegóły dotyczące danego wydarzenia. Informacja to odpowiednio wyselekcjonowane, porównane, przetworzone oraz odpowiednio zinterpretowane i ocenione dane. Aby informacja mogła być przetworzona w wiedzę, musi być aktualna, zrozumiała dla odbiorcy, czytelna, dokładna, łatwa do wykorzystania, związana z teraźniejszością, ukierunkowana na przyszłość i musi pochodzić z pewnego, sprawdzonego źródła. Najwyższy poziom zajmuje mądrość, która najczęściej nie występuje w organizacjach. Na Rysunku 2 przedstawiono relacje między danymi, informacją a wiedzą.

\footnotetext{
${ }^{1}$ OECD - Organizacja Współpracy Gospodarczej i Rozwoju (Organisation for Economic Co-operation and Development).

${ }^{2}$ Gospodarka oparta na wiedzy (GOW) to, według definicji OECD, gospodarka oparta wprost na tworzeniu, traktowanym jako produkcja, oraz dalszym przekazywaniu, czyli dystrybucji oraz praktycznym wykorzystaniu wiedzy i informacji.
} 


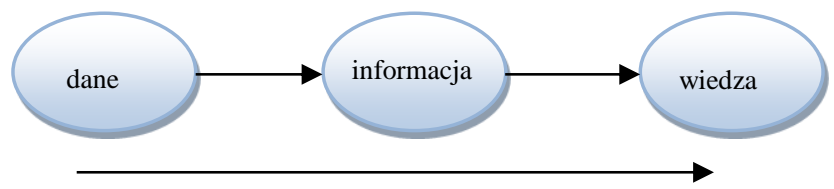

Rysunek 2. Relacje między danymi, informacjami a wiedzą

Źródło: (Kisielnicki 2008, s. 255)

Zarządzanie wiedzą (knowledge management) wymaga wdrożenia informacji poprzez: porównanie jej z inną informacją, wykorzystanie w podejmowaniu decyzji i działań, przemyśleń doświadczonego podmiotu w określonym kontekście. W literaturze przedmiotu znaleźć można mnogość definicji wiedzy. Nonaka i Takeuchi piszą, że o ile informacja jest strumieniem wiadomości, to wiedza jest jego wytworem, zakorzenionym w przekonaniach i oczekiwaniach odbiorcy (Nonaka, Takeuchi 1995).

Według P.F. Druckera wiedza to jedyny ważny współcześnie czynnik w przedsiębiorstwie. Wiedza, zdaniem Druckera, stała się podstawowym środkiem, dzięki któremu przedsiębiorstwo nabywa unikatowy charakter (Drucker 1999, s. 43).

Wiedza to ogół istotnych informacji o otoczeniu oraz umiejętności ich efektywnego wykorzystania. Obejmuje tak elementy teoretyczne, jak i praktyczne. Wiedza zawsze powiązana jest z człowiekiem, bez niego nie może istnieć. Najważniejsze właściwości, które wyróżniają wiedzę spośród wszystkich innych zasobów przedsiębiorstwa, są następujące:

- Wiedza jest nieuchwytna, a jej pomiar jest trudny.

- Wiedza jest niestabilna, czyli w każdej chwili może zniknąć.

- Wiedza w większości przypadków tkwi w umysłach pracowników.

- Wiedza nie jest zużywalna, wręcz odwrotnie - jej poziom zwiększa się w trakcie wykorzystywania.

- Dominujący charakter wiedzy. Od efektywnego wykorzystania zasobu, jakim jest wiedza, zależy przyszłość organizacji i jej przewaga konkurencyjna. Wiedza spełnia rolę nadrzędną w stosunku do wszystkich pozostałych zasobów.

- Wiedza nie może być kupiona w każdej chwili i bardzo często charakteryzuje się długim czasem gromadzenia.

- Wiedza może być używana przez różne procesy w tym samym czasie.

- Nieliniowość - niejednokrotnie tylko jej niewielka porcja może zmienić w sposób istotny sytuację danego podmiotu. Kiedy indziej nawet olbrzymia ilość informacji i wiedzy może okazać się absolutnie bezużyteczna.

Inne cechy wiedzy wskazują Mikuła, Pietruszka-Ortyl i Potocki. Według nich oprócz powyższych, wiedza charakteryzuje się również poniższymi cechami (Mikuła, Pietruszka-Ortyl, Potocki 2002, s. 72-73):

- Wiedza może być tworzona różnymi metodami.

- Wiedza jest względna i niejednoznaczna, a więc może być różnie interpretowana przez poszczególne osoby. 
- Wiedza jest dynamiczna, czyli uchwycenie tylko jej niewielkiej części może doprowadzić do dużego jej przyrostu, jak również posiada zdolność do przyrostu w trakcie jej stosowania.

- Wiedza ulega szybkiej dezaktualizacji.

- Wiedza redukuje niepewność w przypadku ryzykownych przedsięwzięć.

- Wiedza poprzez kodyfikację ulega strukturyzacji w technologiach, procedurach, dokumentacji organizacyjnej, kompetencjach ludzi i bazach danych.

- Wiedza materializuje się w produktach i usługach.

- Wiedza sama w sobie może stać się produktem.

Wśród procedur twórczego systemu zarządzania pracownikami wiedzy wymienia się:

- Identyfikację podstawowych wartości przedsiębiorstwa - jest to procedura budowana na ciągu czynności: informacja - wiedza - emocje - kreatywność - innowacje.

- Ustalenie kluczowych kompetencji - procedury te zapewniają pozycję konkurencyjną względem innych przedsiębiorstw na rynku. Unikatowe umiejętności pozwalają przedsiębiorstwu tworzyć wartość dodaną z punktu widzenia klientów. $\mathrm{W}$ tej procedurze ważne jest to, na ile kluczowe kompetencje całego przedsiębiorstwa są pochodną indywidualnych kompetencji wybranych pracowników.

- Wyodrębnienie kluczowych pracowników wiedzy - obejmuje głównie pracowników przedsiębiorstwa, którzy powinni uczestniczyć w budowaniu pozycji konkurencyjnej przedsiębiorstwa. Powinni się oni charakteryzować unikatowymi umiejętnościami i kompetencjami.

- Monitorowanie otoczenia pod kątem rynku, pomysłów, talentów i kapitału umożliwia ciągły nabór potencjału intelektualnego.

- Określenie wizji, misji i celów strategicznych - procedura odwołująca się do stanu idealnego, który przedsiębiorstwo chce osiągnąć poprzez proces edukacji i rozwoju kompetencji.

- Określenie wariantów strategii personalnej - zorientowane na wspieranie procesów kreowania wiedzy i dzielenia się nią.

- Analiza, ocena i wybór optymalnej w danych warunkach strategii personalnej.

- Implementacja wybranego wariantu strategii personalnej - procedura ta dotyczy strategii wiodącej.

- Prowadzenie ciągłych ocen i modyfikacji funkcjonującego systemu - procedura ma na celu całkowitą likwidację lub częściową neutralizację pojawiających się zagrożeń i barier zarządzania wiedzą.

Zgodnie z klasyfikacją OECD w przedsiębiorstwie wyróżniamy następujące rodzaje zasobów wiedzy:

- Know-what - wiedzieć „co” - odnosi się do faktów i przybiera postać danych, które mogą być łatwo przechowywane i przesyłane.

- Know-why - wiedzieć „dlaczego” - jest to wiedza o związkach przyczynowo-skutkowych, dotyczących praw natury, człowieka i społeczeństwa. 
- Know-how - wiedzieć ,jak” - to wiedza o ludziach i zespołach pracowniczych; jest podstawą praktycznego działania, przybiera postać umiejętności, zdolności i kwalifikacji.

- Know-who - wiedzieć „kto” - to wiedza o tych, którzy posiadają powyższe rodzaje wiedzy.

$\mathrm{Na}$ inny podział wiedzy wskazują Nonaka i Takeuchi, którzy dzielą wiedzę na jawną i ukrytą (Nonaka, Takeuchi 2000, s. 54). Według tego podziału wiedza jawna (dostępna, formalna) to wiedza sformalizowana, którą można łatwo przekazywać za pomocą dostępnych słów, liczb, znaków, rysunków i symboli. Wiedza ta w przedsiębiorstwie jest często wprowadzona do informatycznej bazy danych. Może być kodyfikowana, czyli jasno przedstawiona za pomocą programów komputerowych, szkoleń czy podręczników. Z kolei wiedza ukryta (cicha) to wiedza niewerbalna, niejasna, bardziej zindywidualizowana, intuicyjna, nabywana podczas długotrwałego osobistego doświadczenia, którą trudno zidentyfikować. Taka wiedza nie jest wyrażana za pomocą słów, zatem trudna jest do przekazywania.

Żyjemy w czasach, w których wysoko wykwalifikowani pracownicy są najbardziej poszukiwani na rynku pracy. Przedsiębiorstwa, które pozyskują takich pracowników i inwestują w rozwój ich umiejętności, rozwijają się najbardziej dynamicznie i tworzą największą wartość. Dzięki zgromadzonej w przedsiębiorstwie wiedzy można skuteczniej reagować na zmiany zachodzące w otoczeniu. Umożliwia to również dostosowanie oferty do potrzeb klientów.

\section{Zarządzanie wiedza w MŚP}

W literaturze przedmiotu istnieje wiele definicji zarządzania wiedzą. Zdaniem W. Applehansa, A. Globe'a i G. Laugero wiedza jest informacją stosowaną do rozwiązania danego problemu (Applehans, Glob, Laugero 1999, s. 18).

A. Tiwana definiuje wiedzę jako płynną mieszaninę kontekstowych doświadczeń, wartości, informacji i umiejętności tworzącą ramy dla oceny, rozumienia i przyswajania nowych doświadczeń i informacji (Tiwana 2003, s. 60).

Dostrzeżenie roli wiedzy w uzyskaniu przewagi konkurencyjnej przedsiębiorstw dało asumpt do rozwoju zarządzania wiedzą. Schemat zarządzania wiedzą przedstawiono na Rysunku 3.

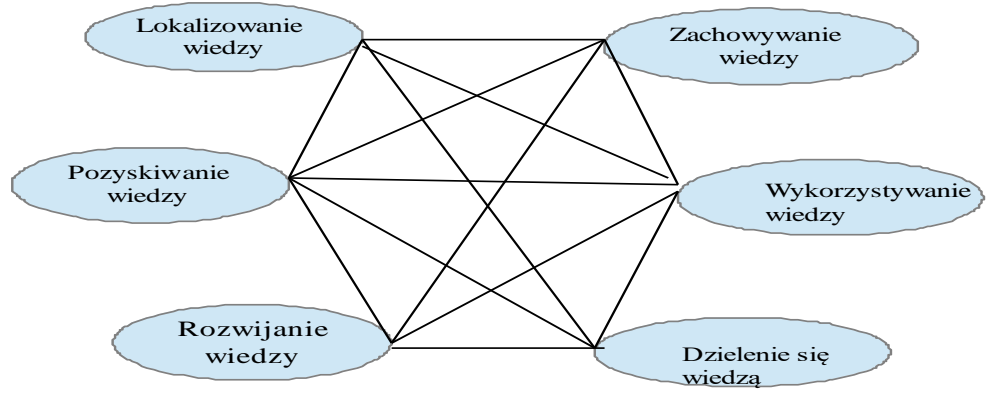

Rysunek 3. Schemat zarządzania wiedzą

Źródło: (Probst, Raub, Romhardt 2002, s. 42) 
Warunkiem skuteczności tych procesów jest pozyskanie odpowiednich zasobów ludzkich oraz zaopatrzenie ich $\mathrm{w}$ niezbędne narzędzia. Przedsiębiorstwa, które chcą odnieść sukces na rynku, starają się pozyskać pracowników o określonych umiejętnościach.

Właściwa komunikacja jest warunkiem skutecznego przesyłania informacji. Dynamiczny rozwój gospodarki elektronicznej powoduje ciągłe poszukiwanie jak najlepszych sposobów jej przekazywania. Nadrzędnym celem informacji jest przekazywanie informacji z jej źródła do odbiorcy. Zależnie od hierarchii zadań i potrzeb kierownictwa wyróżnić można trzy poziomy zarządzania informacją (Kiełtyka 2002, s. 388):

- Strategiczne - obejmuje kierownictwo najwyższego stopnia. Wykorzystywane są tu wykonawcze systemy informacyjne.

- Taktyczne - obejmuje kierowników średniego szczebla. Wykorzystywane są tu sprawozdawcze systemy dla kierownictwa.

- Operacyjne - obejmuje kierowników najniższego szczebla. Wykorzystywane są tu systemy przetwarzania informacji.

W organizacji opartej na wiedzy szczególną rolę odgrywają menedżerowie.

To oni wytyczają drogę do sukcesu (Gruszczyńska-Malec, Rutkowska 2013, s. 20).

R.W. Griffin wskazuje na następujące zachowania przywódcze menedżerów (Griffin 2007, s. 20):

- Są skoncentrowani na zadaniach.

- Są skoncentrowani na pracownikach - pracują nad stworzeniem spójnych zespołów pracowniczych i dbają o zadowolenie pracowników.

- Inicjują strukturę - uważają, że każdy pracownik wie, jakie są oczekiwania względem jego pracy, zatem ustalają formalne linie komunikacji.

- Mają wzgląd na innych - menedżerowie troszczą się o podwładnych, tworzą przyjazną atmosferę w pracy.

Zarządzanie wiedzą doczekało się wielu podejść i modeli, z których trzy można uznać za wiodące kierunki $\mathrm{w}$ tej dziedzinie: model japoński, model zasobowy i model procesowy.

1. Model japoński - jest efektem badań dwóch Japończyków: Nonaki i Takeuchiego, którzy na początku lat 90. opracowali model „spirali wiedzy”, rozwinięty na przestrzeni lat w kompleksowe podejście do zarządzania wiedzą (Nonaka, Takeuchi 2000, s. 96). Podejście japońskie obejmuje dwa wymiary tworzenia wiedzy:

- Wymiar epistemologiczny - w tym wymiarze wiedza zostaje podzielona na wiedzę ukrytą (indywidualną, niesformalizowaną i trudną do przekazywania) oraz dostępną (skodyfikowaną, łatwo przekazywaną za pomocą formalnego języka).

- Wymiar ontologiczny - w tym wymiarze wiedza jest tworzona wyłącznie przez jednostki. Organizacja sama nie może tworzyć wiedzy. Przedsiębiorstwo wspiera twórcze jednostki w tworzeniu wiedzy.

Proces tworzenia wiedzy odbywa się na zasadzie spirali i jest to powtarzający się cykl czterech procesów konwersji wiedzy: 
- Socjalizacja - jest to proces dzielenia się doświadczeniami oraz przekształcania wiedzy ukrytej w ukrytą. Pojedynczy pracownicy mogą zdobywać wiedzę ukrytą na drodze bezpośrednich kontaktów, poprzez obserwację, naśladowanie i pra-ktyczne ćwiczenia.

- Eksternalizacja - jest to proces wyrażania wiedzy ukrytej za pomocą dostępnych pojęć. Podczas tego procesu wiedza ukryta zostaje udostępniona w dialogu w postaci metafor, analogii i dochodzi do jej przekształcenia w wiedzę dostępną.

- Kombinacja - jest to proces przetwarzania wiedzy formalnej, dostępnej, pochodzącej z wnętrza i otoczenia przedsiębiorstwa poprzez selekcjonowanie i kategoryzowanie informacji. W trakcie tego procesu dochodzi do przekształcenia wiedzy dostępnej w dostępną.

- Internalizacja - jest to proces włączania wiedzy dostępnej w obręb wiedzy ukrytej, który wspomaga przekaz werbalny, zapis w dokumentach i przekazywanie ustne. W wyniku tego procesu zachodzi przekształcanie wiedzy dostępnej w ukrytą.

Na Rysunku 4 zaprezentowano japoński proces tworzenia wiedzy.

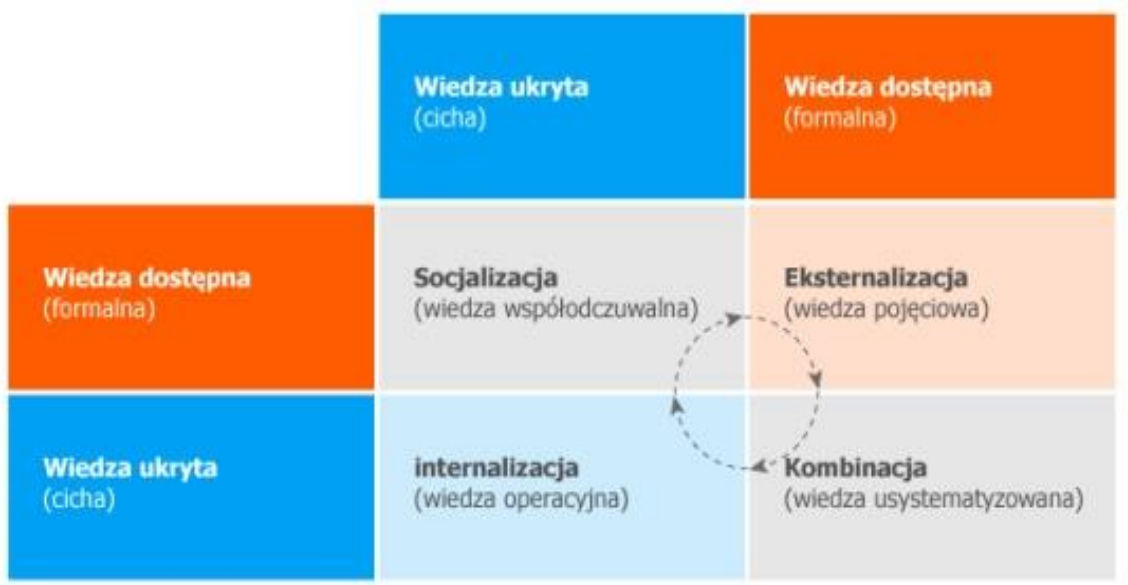

\section{Rysunek 4. Japoński model tworzenia wiedzy}

Źródło: (Nonaka, Takeuchi 2000, s. 96)

2. Model zasobowy - został opracowany w pierwszej połowie lat 90 . przez D.L. Bartona, który uważał wiedzę za najważniejszy zasób przedsiębiorstwa (Grudzewski, Hejduk 2000, s. 29). W modelu tym przyjęto, że dla efektywnego zarządzania wiedzą niezbędne jest istnienie pięciu poniższych elementów:

- kluczowe umiejętności - to umiejętności i wiedza pracowników, systemy zarządzania, normy i systemy wartości;

- wspólne rozwiązywanie problemów;

- eksperymentowanie;

- implementacja nowych narzędzi i technologii;

- importowanie wiedzy. 
W modelu zasobowym to pracownicy gwarantują istnienie wiedzy w organizacji, przez utożsamianie się z jej celami i ciągłe utrzymywanie określonych zasobów wiedzy. Na Rysunku 5 przedstawiono model wiedzy w ujęciu zasobowym.

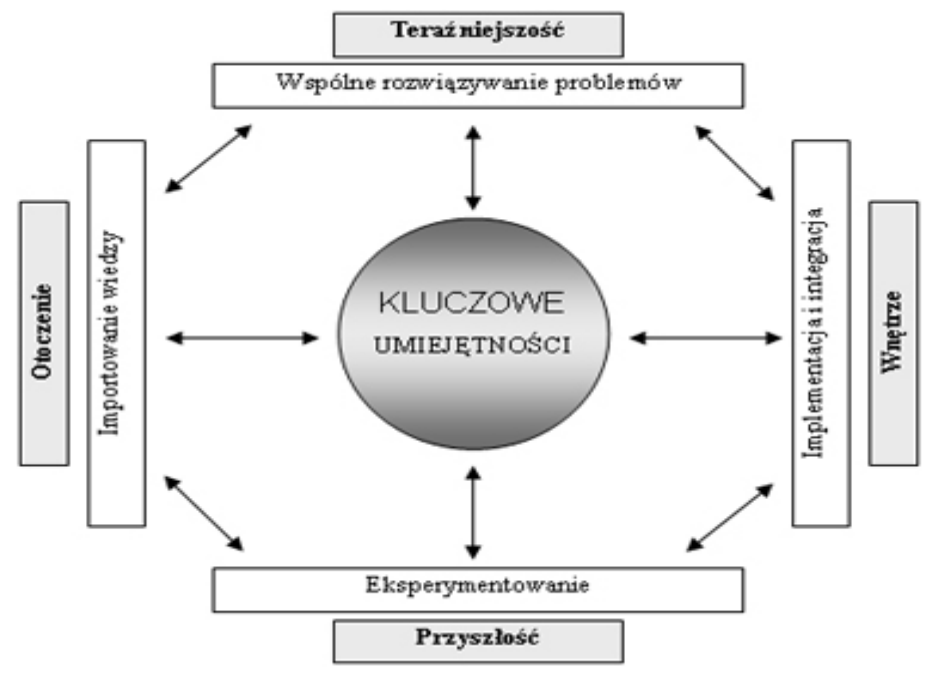

\section{Rysunek 5. Model zasobowy}

Źródło: (Leonard-Barton 1995)

Choć model zasobowy ma solidne podstawy, to jednak nie jest zbyt mocno zakorzeniony w realiach gospodarki przemysłowej i raczej nie spowoduje rewolucji w zakresie tworzenia wiedzy. Model ten nie wyróżnia się zbyt nowatorskim podejściem.

3. Model procesowy - model ten bazuje na rozwiązaniach i doświadczeniach praktycznych, stosowanych w dużych firmach konsultingowych. Znaczący wkład w rozwój koncepcji modelu procesowego wnieśli T. Davenport i L. Prusak z IBM Consulting Group, G. Probst i S. Raub oraz W.R. Bukowitz i R.L. Wilson (Jaśkowiec 2004, s. 26). Opracowali oni model zarządzania wiedzą oparty na trzech procesach:

- Tworzenie wiedzy - polega na inicjatywach, które przedsiębiorstwo podejmuje, by zwiększyć ilość posiadanej wiedzy. Odbywa się to poprzez tworzenie warunków do jej powstawania, pobudzania inicjatyw pracowniczych czy współpracy z firmami zewnętrznymi.

- Kodyfikacja wiedzy - polega na nadawaniu wiedzy organizacyjnej odpowiedniej formy, tak by pracownicy mieli do niej nieograniczony dostęp w każdym czasie.

- Transfer wiedzy - jest realizowany poprzez dwa rodzaje działań:

a) transmisję - polegającą na pobraniu wiedzy z banku wiedzy i przesłaniu jej do potencjalnego odbiorcy;

b) absorpcję - polegającą na przyjęciu wiedzy w celu jej późniejszego wykorzystania. 


\section{Badania poświęcone pozyskiwaniu i wykorzystywaniu wiedzy w przedsiębiorstwach $\mathrm{z}$ sektora MŚP na terenie województwa śląskiego}

$\mathrm{Na}$ potrzeby niniejszego artykułu zostało przeprowadzone badanie wśród 50 firm z sektora MŚP z terenu województwa śląskiego. W badaniu wykorzystano kwestionariusz ankiety. Przedmiotem analizy była intensywność i charakterystyka działań zorientowanych na pozyskiwanie i wykorzystywanie wiedzy w przedsiębiorstwach. Badani mieli możliwość wielokrotnego wyboru odpowiedzi. Badanie zostało przeprowadzone w drugim kwartale 2017 roku.

Jeśli chodzi o źródła pozyskiwania wiedzy w przedsiębiorstwach, okazało się, że spośród badanych firm 76 pozyskuje wiedzę ze szkoleń i kursów, 40 firm czerpie wiedzę z wcześniejszych doświadczeń nowo zatrudnionych pracowników, a 73 firmy uzyskują informacje od klientów; 34 firmom pozyskiwanie wiedzy umożliwiają firmy konsultingowe. Strukturę tych wyników zaprezentowano na Rysunku 6.

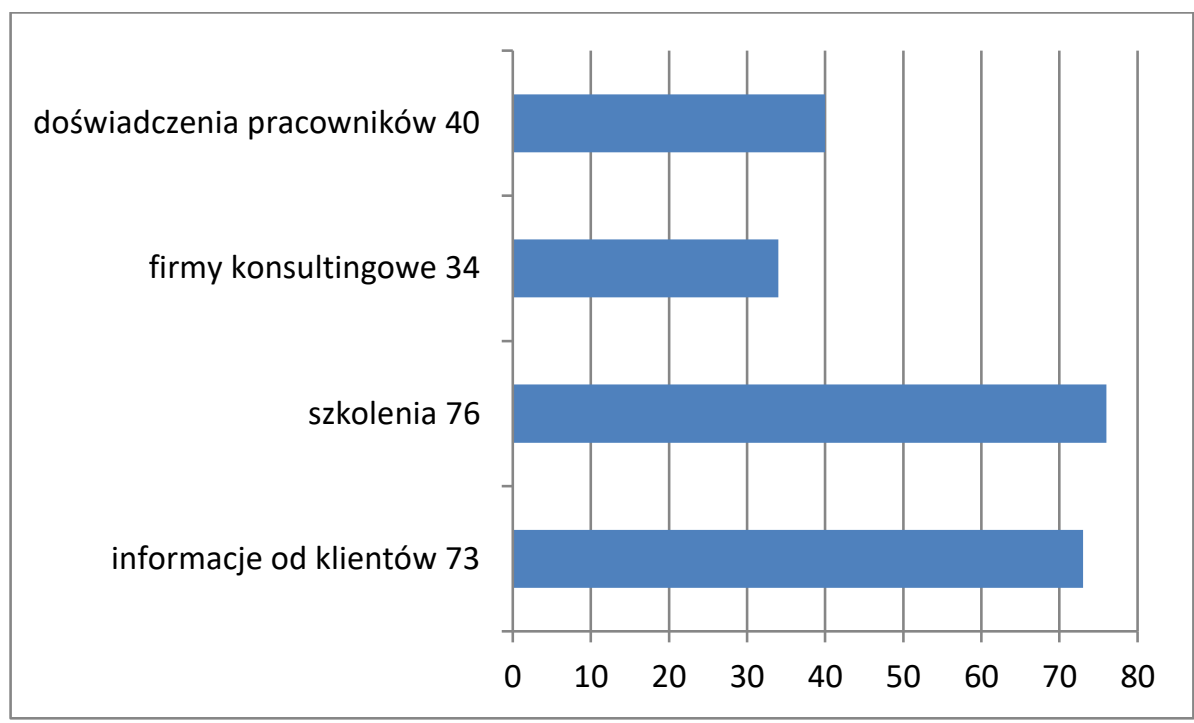

Rysunek 6. Źródła pozyskiwania wiedzy w badanych przedsiębiorstwach

Źródło: Opracowanie własne

Na pytanie o rozpowszechnianie wiedzy w badanych przedsiębiorstwach uzyskano następujące odpowiedzi:

- W przedsiębiorstwie istnieją warunki do wymiany doświadczeń między pracownikami - 74 odpowiedzi.

- Pracownicy różnych działów współpracują ze sobą - 80 odpowiedzi.

- W przedsiębiorstwie podejmowane są działania mające na celu poprawę przepływu wiedzy -47 odpowiedzi.

- Pracownicy i przełożeni mają nieograniczony dostęp do wiedzy w przedsiębiorstwie -80 odpowiedzi. 
Wyniki te zaprezentowano na Rysunku 7.

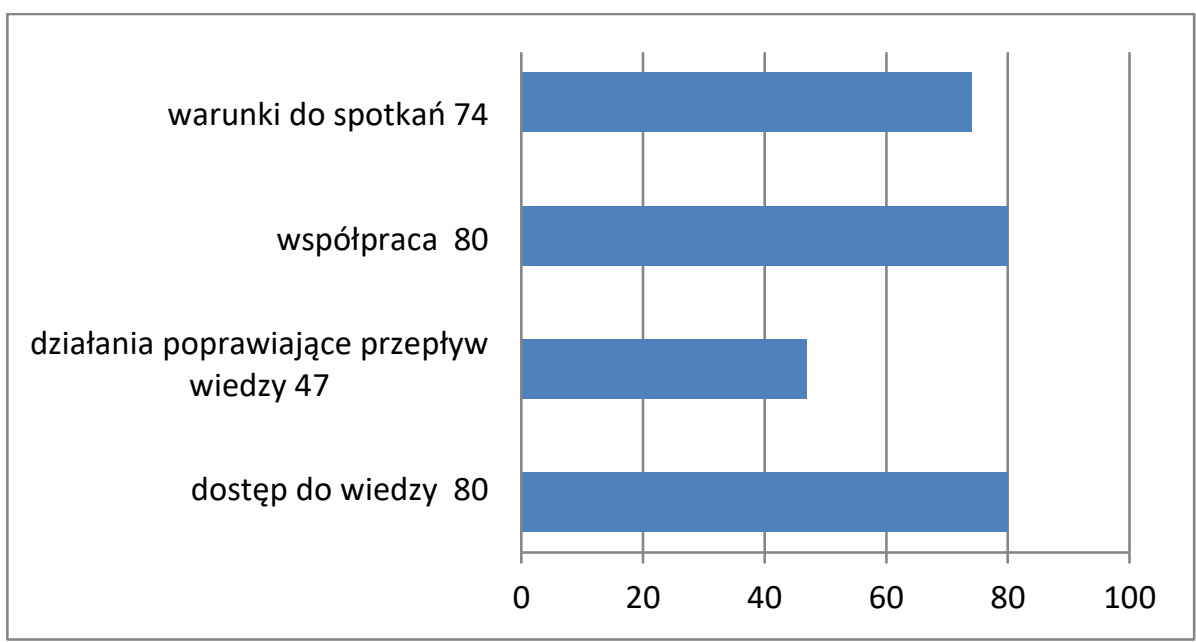

Rysunek 7. Ocena rozpowszechniania wiedzy w badanych przedsiębiorstwach

Źródło: Opracowanie własne

Kolejne pytanie dotyczyło wdrażania i otwartości na wiedzę. W odpowiedziach 60 badanych deklaruje, że na bieżąco identyfikuje swoje braki i potrzeby w zakresie wiedzy, a 71 uważa wiedzę za podstawowy czynnik konkurencyjności. Według 77 wiele pomysłów powstaje dzięki sprawnemu przepływowi wiedzy w firmie, natomiast 60 podaje fakt częstego zgłaszania pomysłów przez pracowników. Strukturę odpowiedzi na to pytanie zobrazowano na Rysunku 8 .

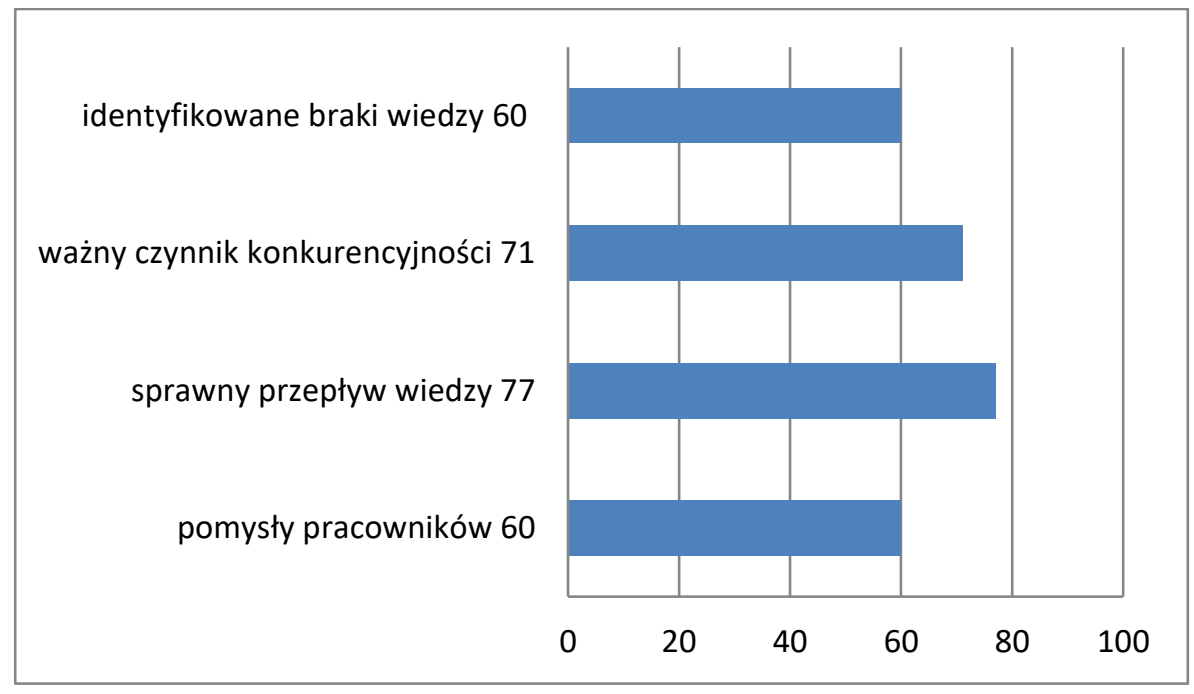

Rysunek 8. Wdrażanie i otwartość na wiedzę w badanych przedsiębiorstwach

Źródło: Opracowanie własne 
Na pytanie o dostęp do technologii informatycznych 97 badanych odpowiedziało, że w przedsiębiorstwie wykorzystuje się podstawowe technologie informatyczne, 6 ankietowanych stwierdziło, że korzysta $z$ systemów magazynowania danych. Informatyczne systemy komunikacyjne, jak na przykład intranet, grupy dyskusyjne, wykorzystuje 61 badanych, a z systemów eksperckich korzysta 6 respondentów. Wartości te przedstawiono na Rysunku 9.

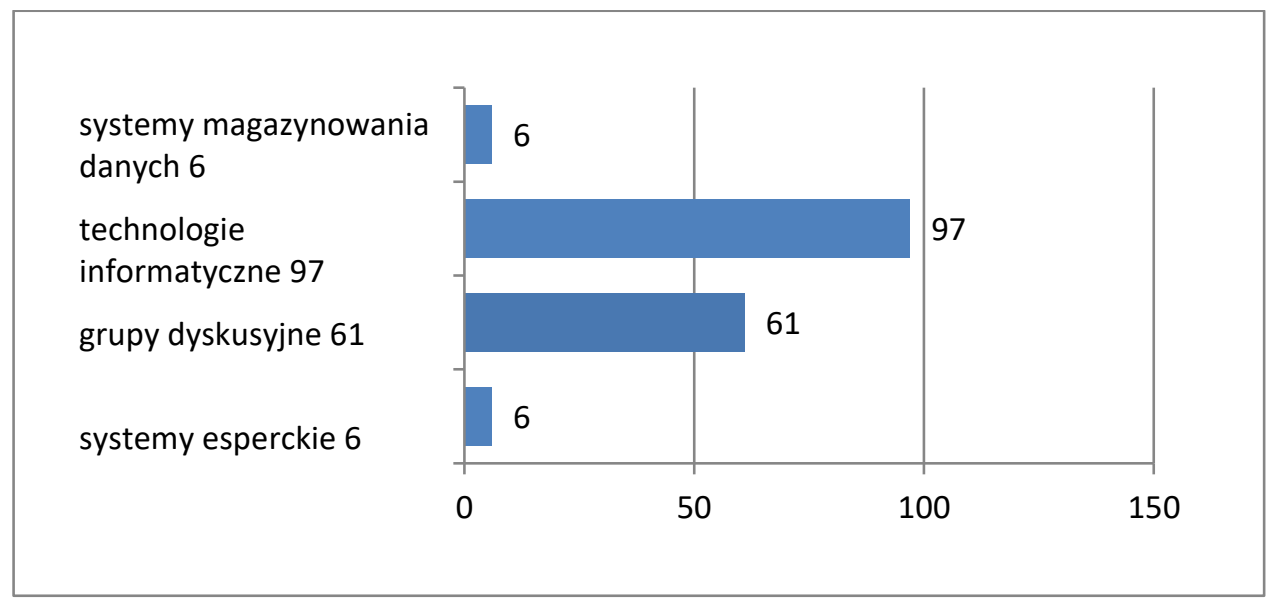

Rysunek 9. Wykorzystywanie technologii informatycznych w badanych przedsiębiorstwach

Źródło: Opracowanie własne

\section{Podsumowanie}

Gospodarka XXI wieku to bez wątpienia gospodarka oparta na wiedzy. Przedsiębiorstwa, które świadomie pozyskują wiedzę i inwestują w jej rozwój, osiągają przewagę konkurencyjną na rynku. Skutecznym wsparciem dla rozwoju wiedzy w przedsiębiorstwach z sektora MŚP jest wykorzystywanie nowoczesnych technologii, które pozwalają na gromadzenie i przekazywanie wiedzy. Wdrażanie nowoczesnych technologii informatycznych, poszerzanie i rozpowszechnianie wiedzy wśród pracowników poprzez udział w szkoleniach, konferencjach, zmiany w strukturze organizacyjnej pozwalają na osiągnięcie przewagi konkurencyjnej.

We współczesnym przedsiębiorstwie ludzie powinni być traktowani jak najcenniejsze aktywa, a przedsiębiorstwa powinny dbać o ich stały rozwój. Podczas gdy inne aktywa $z$ biegiem czasu ulegają deprecjacji, wiedza tkwiąca $w$ umysłach pracowników ma zdolność do pomnażania się. Wiedza, jaka znajduje się w posiadaniu przedsiębiorstw, odróżnia ją od pozostałych podmiotów na rynku, jest najważniejszym czynnikiem warunkującym osiągnięcie sukcesu.

Wiedza, w znacznie większym stopniu niż inne czynniki, może przyczyniać się do tworzenia wartości dodanej. Stąd w modelu gospodarki opartej na wiedzy wskazuje się na zasoby ludzkie jako na fundament zdobywania konkurencyjności 
i wzrostu innowacyjności. Podkreśla się, że inwestycje związane z rozwojem zasobów ludzkich stanowią najkorzystniejszą lokatę kapitału.

Wiedza zgromadzona w umyśle pracowników stanowi niematerialne zasoby przedsiębiorstwa. Niezwykle ważne jest stworzenie odpowiedniego systemu motywacyjnego, aby pracownicy pogłębiali swoją wiedzę i dzielili się nią (Kiełtyka, Nazarko (red.) 2006, s. 132). W koncepcji zarządzania wiedzą niezwykle ważne jest tworzenie warunków do efektywnej współpracy i wymiany informacji. W związku z tym wiedza, jako niezwykle cenna wartość, powinna być przedmiotem szczególnego zainteresowania zarządu i kierownictwa organizacji.

Co sprawia, że niektóre firmy odnoszą sukces na rynku, a inne nie? Wpływ na to ma wiele czynników, jednak jednym z najważniejszych jest możliwość korzystania $\mathrm{z}$ wiedzy zgromadzonej $\mathrm{w}$ przedsiębiorstwie. Kapitał intelektualny stanowi najcenniejsze aktywa firmy. Jego podstawą jest zaś wiedza, która może być wkorzystana przez przedsiębiorstwo. Praktyka pokazuje, że przedsiębiorstwa niejednokrotnie mają duże problemy $\mathrm{z}$ wprowadzaniem zmian, które są niezbędne $\mathrm{w}$ celu skutecznego wykorzystywania wiedzy.

\section{Literatura}

1. Adamkiewicz-Drwiłło H.G. (2002), Uwarunkowania konkurencyjności przedsiębiorstwa, Wydawnictwo Naukowe PWN, Warszawa.

2. Applehans W., Globe A., Laugero G. (1999), Managing Knowledge. A Practical Web-Based Approach, Addison-Wesley.

3. Drucker P.F. (1999), Społeczeństwo postkomunistyczne, Wydawnictwo Naukowe PWN, Warszawa.

4. Griffin R.W. (2007), Podstawy zarządzania organizacjami, Wydawnictwo Naukowe PWN, Warszawa.

5. Grudzewski W.M., Hejduk I.K. (2000), Kreowanie systemów zarządzania wiedza podstawa dla osiagnięcia przewagi konkurencyjnej współczesnych przedsiębiorstw, [w:] Grudzewski W.M., Hejduk I.K. (red.), Przedsiębiorstwo przyszłości, Difin, Warszawa, s. 25-39.

6. Gruszczyńska-Malec G., Rutkowska M. (2013), Strategie zarzadzania wiedza, PWE, Warszawa.

7. Jaśkowiec M. (2004), Zarządzanie wiedza jako kluczowy czynnik sukcesu i przewagi konkurencyjnej organizacji XXI wieku, [w:] Borowiecki R., Kwieciński M. (red.), Informacja $i$ wiedza $w$ zintegrowanym systemie zarządzania, Kantor Wydawniczy Zakamycze, Kraków, s. 21-34.

8. Kiełtyka L. (2002), Komunikacja w zarzadzaniu, Agencja Wydawnicza Placet, Warszawa.

9. Kiełtyka L., Nazarko I. (red.) (2006), Metody i procesy usprawniania zarzadzania przedsiębiorstwem. Wybrane zagadnienia, Wydawnictwo Menedżerskie PTM, Warszawa.

10. Kisielnicki J. (2008), Zarzadzanie, PWE, Warszawa.

11. Król H., Ludwiczyński A. (2006), Zarzadzanie zasobami ludzkimi. Tworzenie kapitału ludzkiego organizacji, Wydawnictwo Naukowe PWN, Warszawa.

12. Leonard-Barton D. (1995), Wellsprings of Knowledge. Building and Sustaining the Sources of Innovaion, Harvard Business School Press, Boston.

13. Malhotra Y. (2001), It's Time to Cultivate Growth, „Leading Views”, March.

14. Mikuła B., Pietruszka-Ortyl A., Potocki A. (2002), Zarządzanie przedsiębiorstwem XXI wieku. Wybrane koncepcje i metody, Difin, Warszawa. 
15. Nonaka I., Takeuchi H. (1995), The Knowledge Creating Company - How Japanese Companies Create the Dynamic of Innovation, Oxford University Press, New York.

16. Nonaka I., Takeuchi H. (2000), Kreowanie wiedzy w organizacji. Jak spółki japońskie dynamizuja procesy innowacyjne, Poltext, Warszawa.

17. Owen J. (2003), Zarzadzanie. Czego nie uczq w szkołach biznesu, PWE, Warszawa.

18. PARP (2017), Raport o stanie sektora matych i średnich przedsiębiorstw w Polsce, Polska Agencja Rozwoju Przedsiębiorczości, Warszawa.

19. Probst G., Raub S., Romhardt K. (2002), Zarządzanie wiedza w organizacji, Oficyna Ekonomiczna, Kraków.

20. Stankiewicz M.J. (2002), Konkurencyjność przedsiębiorstw. Budowanie konkurencyjności przedsiębiorstwa w warunkach globalizacji, TNOiK „Dom Organizatora”, Toruń.

21. Tiwana A. (2003), Przewodnik po zarządzaniu wiedza. E-biznes $i$ zastosowanie CRM, Agencja Wydawnicza Placet, Warszawa.

22. Ustawa z dnia 2 lipca 2004 r. o swobodzie działalności gospodarczej (Dz.U. 2004 nr 173 poz. 1807 , z późn. zm.).

\title{
THE INFLUENCE OF KNOWLEDGE ON THE COMPETITIVENESS OF ENTERPRISES FROM SME SECTOR
}

\begin{abstract}
Companies constantly search for ways to strengthen their competitive advantage. Achievement of this objective largely depends on the proper management of the knowledge. Knowledge is now one of the most important resources of any business. Special attention should be paid to the knowledge workers, which for the most part is in their minds. Therefore, the competitiveness of companies largely decide outstanding units and business teams and their possessed knowledge. The aim of the research is to present the impact of knowledge on building competitive advantage of small and medium-sized enterprises. The study was conducted on a group of randomly selected companies in Poland, Silesian Voivodeship, using method survey list. Results of the study allow conclude that knowledge-based companies are the most competitive companies.
\end{abstract}

Keywords: competitivness, knowlefge, knowledge managemement, SME (small and medium enterprises sector) 